\title{
ANKRD26 Gene
}

National Cancer Institute

\section{Source}

National Cancer Institute. ANKRD26 Gene. NCI Thesaurus. Code C151924.

This gene plays a role in platelet functions, adipogenesis and appetite. 